\title{
JAZYKOVÉ PLÁNOVANIE V LINGVISTICKOM DIELE VLADIMÍRA HURBANA VLADIMÍROVA
}

Štúdia sa venuje problematike jazykového plánovania v jazykovednom diele Vladimíra Hurbana Vladimírova (VHV) v období medzi dvoma svetovými vojnami. Korpusové plánovanie (corpus planning) sa uplatňuje nielen v materskej krajine, ale aj v jazykovej enkláve. Zložitá jazyková situácia v medzivojnovom Československu - formovanie podoby modernej slovenčiny a vznik nových Pravidiel slovenského pravopisu - sa odrazila v jazyku dolnozemských Slovákov. S ideou pozdvihovania a posilňovania povedomia Slovákov o materinskom jazyku sa VHV aktívne zapojil do kultúrno-politických bojov o slovenský jazyk, pričom jeho platformou sa stali miestne periodiká a jazykové kurzy pre domáce obyvatel'stvo. Hurbanovo dielo otvára viaceré otázky o intenzite a stabilizácii jazykového korektívu v enkláve v d’alších generáciách používatel'ov slovenčiny.

Klúčové slová: jazykové plánovanie, kultivačné a normatívne lingvistické aktivity; Pravidlá slovenského pravopisu (1931); jazykovedné práce VHV; praktické jazykové kurzy v Starej Pazove; zápas o identitu slovenčiny v enkláve.

The study focuses on language planning in the linguistic works of Vladimir Hurban Vladimirov (VHV) in the period between two world wars. Corpus planning is applied not only in the parent country but also in the language enclave. The complex language situation in interwar Czechoslovakia - the formation of the modern Slovak language and the emergence of New Slovak Orthography was reflected in the language of Vojvodina Slovaks. With the idea of raising and strengthening the Slovaks' awareness of the mother language, VHV actively participated in the cultural and political fight for the Slovak language, its platform becoming local periodicals and language courses for the local population. Hurban's work opens a number of questions about the intensity and stabilization of language corrective in enclaves in future generations of Slovak users.

Key words: language planning, culture and normative linguistic activities; Rules of Slovak Orthography (1931); linguistic work of VHV; practical language courses in Stara Pazova; a struggle for identity of the Slovak language in an enclave.

Ak dnes hovoríme o jazykovej politike, máme na mysli kategórie, ktoré sú spojené s uvedomelým pôsobením spoločnosti na jazyk. Vplyv horizontálne i vertikálne diferencovanej society i jednotlivca na fungovanie, vývin, interferenciu a vzájomné kontakty medzi jazykmi (varietami jazyka, „subjazykmi“ - nárečiami a inými varietami v jazykových spoločenstvách) sú v kultúrnych dejinách každého národa stále živé a aktuálne. Jazyková politika sa tiež viaže na oblast' teoretických a empirických výskumov, tesne spätých s premenou statusu a používania jazykov v modernej spoločnosti a rovnako je spojená s formovaním politiky v oblasti vyučovania cudzích jazykov. Otázkam vývoja a vzájomného pôsobenia jazykov sa v súčasnosti venujú lingvisti na celom svete $\mathrm{v}$ rozmanitých formách i prístupoch, od základných teoretických i aplikovaných zadaní, až po špecifické rozpracovanie problematiky teórie spisovného jazyka, jazykovej kultúry, grafematiky, sociolingvistiky, kognitívnej lingvistiky, 
ekolingvistiky a pod. (Kristal, 1988, 2003) Jazykovú politiku tak môžeme definovat' ako súbor oficiálnych a verejne deklarovaných aktivít regulujúcich konkrétnymi legislatívnymi opatreniami používanie jazyka (variet jazyka, jazykových kódov) v jednotlivých oblastiach verejného života. Možno ju chápat’ ako hyponymum k jazykovému plánovaniu, ktoré v sebe zahŕňa rozmanité aktivity zamerané na modifikáciu alebo (naopak) stabilizáciu jazykového správania istého rečového spoločenstva, teda plánovanie „situácie“ spisovného jazyka. Podl’a toho, kam plánovanie smeruje, rozlišujeme dve dimenzie jazykového plánovania: 1. statusové plánovanie (status planning) zamerané na určenie „statusu“ jazyka vo vzt’ahu k iným jazykom (emancipácia, prestíž, kondícia, sociálna sila jazyka) a 2. korpusové plánovanie (corpus planning) namierené na „korpus“, teda samotnú podobu jazyka (normatívna činnost', starostlivost' o jazyk, jazyková kultúra). Spomínané spoločensky relevantné plánovacie aktivity vyvíjajú najmä štátne a nadnárodné inštitúcie (ministerstvá, európske inštitúcie), vzdelávacie a kultúrne inštitúcie i jednotlivci. (Nekvapil 2017, Bogoczová 2010).

Na tomto mieste je dôležité pripomenút', že jazykové plánovanie ako systém sociálnych a ideologických princípov namierených na fungovanie, rozvoj a úlohu jazykov v živote istého národa, sa neuplatňuje iba v administratívno-právnych a štátom vymedzených hraniciach používania jazyka, ale aj v jazykových enklávach či v diaspórach. (Dudok 2002: 42, Sokolović 2014). Tu sa uplatňuje najmä korpusové plánovanie (nesúce v sebe atribúty autoritatívnosti a inštitucionálnosti), ciel'om ktorého je štandardizácia, reforma či revitalizácia jazyka, jeho kultivovanie i ochrana, ako aj vytváranie platformy pre neproblémovú komunikáciu medzi používatel'mi toho istého jazyka.

Zámerné ovplyvňovanie jazyka smerujúce k plánovanému jazykovému správaniu dostávalo sa na najvyššie priečky pomyselného rebríčka „kultivačných“ aktivít najmä v období konštituovania moderných národných štátov i jazykov. Inak tomu nebolo ani po vzniku samostatnej Československej republiky (ČSR), ked' ústava nového štátu (1920) zákonom č. 122 Zb. v §1. zakotvila, že štátnym, oficiálnym jazykom republiky je jazyk československý, ${ }^{1}$ ktorý sa podl’a $\S 4$ používa na území Slovenska „spravidla po slovensky“. ${ }^{2}$ Tvorcovia ústavných zákonov si nepochybne dobre uvedomovali, že jazyk československý reálne neexistuje, a tak zákonom ustanovili jeho dvojaké znenie - české a slovenské. Hoci použivanie jazykov priamo vymedzoval zákon, dve jazykové „,podoby“ spôsobovali v praxi mnohé nedorozumenia a problémy, ktoré sa čoskoro prejavili najmä v oblasti normovania gramatiky a slovníka spisovného jazyka. Nová podoba slovenčiny bola formovaná na pozadí politickej doktríny jednotného československého národa a jazyka, pričom bola sčasti podporovaná

${ }^{1}$ Zákon 122/1920 Zb. ustanovoval zásady jazykového práva v Československu v tomto znení: „Jazyk československý jest státním, oficielním jazykem republiky (čl. 7. smlouvy mezi čelnými mocnostmi spojenými a přidruženými a mezi Československem, podepsané v St. Germain en Laye dne 10. záŕí 1919).“

2 Ústavný zákon č. 122/1920 Zb. v §4 zakotvil: „Uživajíce jazyka státního, oficielního, úřady v onom území republiky, jež před 28. říjnem 1918 náleželo ku královstvím a zemím na říšské radě zastoupeným, nebo ku království Pruskému, úradují zpravidla po česku, na Slovensku zpravidla po slovensku. Slovenské úřední vyřrizení k podání českému nebo úřední vyřízení české k podání slovenskému pokládá se za vyřízení, jež stalo se v jazyku podání. Dostupné na: < http://spcp.prf.cuni. $\mathrm{cz} / \mathrm{lex} / 121-20 . \mathrm{htm}>$ [cit. 01. 02. 2019]. 
aj teóriou o neschopnosti spisovnej slovenčiny stat' sa moderným jazykom vedy a civilizácie. Takéto tvrdenia vyvolávali ostrú odbornú i spoločenskú kritiku a najmä medzi jazykovedcami viedli k dlhotrvajúcim polemikám a sporom. A tak sa v mladučkom Československu predmetom rozsiahlych diskusií, (často neúprosných) útokov i obrán stala aj kodifikovaná podoba (novej) slovenčiny.

Jazykovedný zápas o slovenčinu v tridsiatych rokoch 20. storočia korešpondoval so zápasom politickým. Na Slovensku sa totiž už v prvom desat'ročí existencie ČSR sformovala silná opozícia proti československej vláde, ktorá sa usilovala riešit' slovenskú otázku v zmysle presadzovania autonómie. ${ }^{3}$ Do politického boja o slovenskú autonómiu tak nebadane vkízol i boj o kodifikovanú podobu jazyka. V súvislosti s pripravovanými novými pravidlami slovenského pravopisu denník Slovák informoval, že ich síce pripravujú v Matici slovenskej, ale na čele autorského kolektívu stojí český slavista a dialektológ Václav Vážný (1892 - 1966). Čast' slovenskej kultúrnej verejnosti i početná slovenská inteligencia boli pobúrené. Zápas o identitu slovenčiny sa rozbehol naplno - norma a kodifikácia spisovného jazyka sa z vedeckých stolov preniesli do parlamentných lavíc a stali sa predmetom politických bojov. Mladé Československo podporovalo tých filológov a kultúrnych dejatel'ov, ktorí tvrdili, že čeština a slovenčina tvoria jeden jazyk, a preto sa má spisovná slovenčina v d’alšom vývine približovat' $\mathrm{k}$ češtine. $\mathrm{V}$ opozícii s oficiálnou teóriou o československom jazyku v dvoch „zneniach“ bola skupina pracovníkov Matice slovenskej, najmä Jozef Škultéty a Henrich Bartek. Vášnivé polemiky a neúprosný boj medzi dvoma lingvistickými tábormi vyvrcholil po vydaní Pravidiel slovenského pravopisu.

Ako jeden z prvých proti novým Pravidlám (vydaných v roku 1931 pod redakciou Václava Vážného) ${ }^{4}$ otvorene vystúpil vtedy ešte mladý doktor filozofie Henrich

${ }^{3}$ Slovenskí opoziční politici (najmä predstavitelia Slovenskej l’udovej strany a Slovenskej národnej strany) sa vo svojom (autonomistickom) programe opierali predovšetkým o dva dokumenty - o Pittsburskú dohodu, v ktorej sa hovorí, že v rámci ČSR bude mat' Slovensko vlastnú administratívu, snem, súdy a slovenčinu ako úradný jazyk a o tzv. tajnú klauzulu k Martinskej deklarácii (kauza známa ako vacuum iuris - bezprávny stav). V novoročnom čísle časopisu Slovák vyšiel v roku 1928 článok, v ktorom sa uvádza, že existuje tajná klauzula k Martinskej deklarácii (prijatej 30. októbra 1918) hovoriaca o tom, že v deň desiateho výročia vzniku ČSR sa skončí platnost' tejto deklarácie a na Slovensku nastane bezprávny stav. Slováci sa vtedy sami rozhodnú, v akom štátnom usporiadaní budú žit' - či zostanú v ČSR, či vytvoria samostatný štát alebo sa spoja s iným národom. A hoci túto klauzulu nikto nikdy nevidel, stala sa nástrojom na rozpútanie vášní a rozruchu medzi slovenským obyvatel'stvom a zároveň bola jedným z prostriedkov podporujúcich autonomistické snaženia niektorých politických strán.

${ }^{4}$ Prvé Pravidlá slovenského pravopisu (PSP) boli výsledkom kolektívnej práce pätčlennej komisie Jazykového odboru Matice slovenskej - pravopisnej komisie pod vedením Václava Vážneho. Vydala ich Matica slovenská v roku 1931 ako jediné ministerstvom školstva a národnej osvety schválené vydanie a zároveň ako učebnú pomôcku pre všetky typy škôl v ČSR. Pri tvorbe Pravidiel uplatňoval hlavný redaktor Václav Vážný oficiálnu teóriu o jednotnom československom národe a československom jazyku - na spisovnú slovenčinu aplikoval tézu o československom jazyku s dvoma „spisovnými zneniami“ a v úsilí priblížit' spisovnú slovenčinu češtine porušil na viacerých miestach tzv. martinský úzus, ktorý mal v spisovnej slovenčine pomerne pevnú tradíciu. Kodifikačné zásahy do spisovnej slovenčiny v duchu tejto teórie sa podarilo odstránit’ až v nových Pravidlách slovenského pravopisu vydaných v roku 1940. 
Bartek $(1907-1986)^{5}$, ktorý konštatoval, že v Pravidlách chýba jednotiaci princíp pri posudzovaní rečových javov; najmä v hláskosloví, v kvantite a v nových slovách možno pozorovat' neprimeranú vol'nost' a navrhoval odstránenie „konfliktnosti medzi dvoma formami: grafickou a zvukovou podobou jazyka" (Žigo 2007: 166). Do celospoločenskej diskusie o novej podobe slovenčiny sa okamžite zapojila aj široká verejnost' i známi spisovatelia. Napríklad, slovenský literát Ján Smrek v časopise Elán na margo nových pravidiel priam poeticky konštatoval, že Pravidlá slovenského pravopisu „obrátili nám naruby stovky slov, ktoré v ničom nebolo treba reformovat', tým menej deformovat'." 6 Zásadnou reakciou na nové pravidlá a pravopisný slovník bol vznik časopisu Slovenská reč (1932) ako mesačníka pre záujmy spisovného jazy$\mathrm{ka},{ }^{7}$ ciel'om ktorého bolo bránit' matičný úzus, ako to sformuloval jeho vedúci redaktor Henrich Bartek: „Slovenská reč má v prvom ročníku rozšírit’ znalost' dobrého spisovného úzu, ktorý je výsledkom sústavnej práce Matice slovenskej.“ (Bartek 1933: 278). Odmietnutie Pravidiel slovenského pravopisu (1931) slovenskou kultúrnou verejnost'ou ${ }^{8}$ malo za následok vytvorenie dvoch „opozičných“ centier pracujúcich na poli normovania a kodifikácie spisovnej slovenčiny. ${ }^{9}$ Príčiny jazykových „sporov“ osvetlil Henrich Bartek v článku uverejnenom v časopise Slovenská reč, v ktorom konštatuje, že Pravidlá slovenského pravopisu (1931) narušili „zásadné stanoviská dobrého rečového úzu, ktorých sa pridŕža Matica slovenská v svojich vydaniach“, preto došlo k sporu „o nové Pravidlá, preto Slovenská reč, najmä v prvom ročníku, oboznamovala verejnost' so staršími poučkami o správnosti jazykovej. Ved' bolo po-

5 Od septembra 1932 do mája 1933 pracoval Henrich Bartek striedavo v Ústredí slovenských ochotníckych divadiel v Martine a v Matici slovenskej, kde sa v máji 1933 stal referentom Jazykového odboru Matice slovenskej a redaktorom časopisu Slovenská reč, ktorý „viedol v puristickom duchu“ (Ondrejovič 2007: 131). Z pozície referenta jazykového odboru sa zúčastňoval na revízii Pravidiel slovenského pravopisu, zásadne odmietajúc umelé zbližovanie češtiny a slovenčiny, resp. jej bohemizovanie.

${ }^{6}$ Podrobne pozri článok pod názvom Slovenčina sa nestala slabým odvarom češtiny uverejnený v denníku Pravda. Dostupné na: <https://spravy.pravda.sk/domace/clanok/173232-slovencina-sa-nestala-slabym-odvarom-cestiny/> [cit. 01. 02. 2019].

${ }^{7}$ Okolo časopisu Slovenská reč sa sformovala generácia jazykovedcov, ktorí si uvedomovali nevyhnutnost' systematického vedeckého výskumu slovenčiny v zmysle posilňovania jej identity a stability normy a kodifikácie.

${ }^{8}$ Už koncom roku 1931 sa proti Pravidlám zdvihla vlna odporu, na čele ktorej stáli najmä prívrženci autonómie Slovenska v rámci ČSR. Okrem hlasistov sa v tejto otázke vzácne zhodli aj predstavitelia inteligencie oboch hlavných konfesií - katolíci i evanjelici, autori združení okolo Spolku svätého Vojtecha i spolku Tranoscius. „Približovat' slovenčinu k češtine najmä vtedy, ked’ sa táto posledná zo svojich zásad nepohne, je politická lingvistika, "napísal Martin Rázus v Národných novinách, „lebo má ciel’ politický a nie čisto lingvisticko-vedecký.“ Protesty vyústili do petície popredných slovenských intelektuálov, ktorí žiadali Maticu slovenskú o vydanie opravených Pravidiel. Jedným zo signatárov tejto petície bol Ján Smrek, ktorý v časopise Elán napísal: „Pravidlá slovenčiny sa musia tvorit' neodvisle z nej samej, z jej vlastných základov a podl’a jej ducha - tak káže čistá veda.“ Dostupné na: <https://spravy.pravda.sk/domace/clanok/173232-slovencina-sanestala-slabym-odvarom-cestiny/> [cit. 1.2. 2019].

${ }^{9}$ Prvé centrum zostalo v Matici slovenskej, kde na jeho podporu vznikol v roku 1932 časopis Slovenská reč. Druhé centrum sa vytvorilo v Učené společnosti Šafaříkové a okolo jej revue, časopisu Bratislava, ktorý vychádzal v rokoch 1927 - 1937 s jasným oficiálnym čechoslovakistickým zameraním v jazykovej i politickej otázke. (Švagrovský 2006: 338) 
trebné zverejnit' tajnosti rečového úzu Matice slovenskej, ktorý je výsledkom práce Sama Czambla, Jozefa Škultétyho a Jaroslava Víčka, ba nejedno dobré poučenie o správnosti jazykovej pochodí od Štefana Krčméryho a Rudolfa Kl’ačku.“ (Bartek 1933: 278). Nové Pravidlá odmietla nielen početná skupina jazykovedcov, ale aj široká verejnost', kultúrni a politickí dejatelia a neprijala ich ani spisovatel'ská obec. Už v marci 1932 sa valné zhromaždenie Matice slovenskej uznieslo na potrebe revízie Pravidiel (išlo im o reformu spisovnej slovenčiny na základe pevných zásad vychádzajúcich z vnútorných zákonov národného jazyka) a sformovalo osobitnú pravopisnú komisiu pod vedením Jozefa Škultétyho, ktorá bola poverená pripravit' opravené vydanie Pravidiel.

Samotná jazyková prax bola na Slovensku až do konca tridsiatych rokov 20. storočia nejednotná - vo vydaniach Matice slovenskej a v Národných novinách sa uplatňoval martinský úzus, kým na úradoch a v školách sa pridržiavali Pravidiel z roku 1931. Opravené Pravidlá slovenského pravopisu boli pripravené do tlače v roku 1939, avšak do rukopisu zasiahla komisia pod vedením vtedajšieho ministra školstva a národnej osvety Jozefa Siváka, ktorá predložený text neschválila. Ďalšie Pravidlá vydala Matica slovenská v roku 1940 - vydanie vychádzalo z matičného úzu a vytvorilo predpoklady na organický vývin spisovného jazyka v nasledujúcom období. ${ }^{10}$

Zložitú jazykovú situáciu v Československu pomerne cielene sledoval - a pravidelne na ňu $\mathrm{v}$ domácom prostredí aj reagoval - staropazovský rodák, evanjelický kňaz a literát Vladimír Hurban Vladimírov $(1884-1950)^{11}$. V spomínanom období

${ }^{10}$ Autori nových Pravidiel (1940) zhrnuli zásadné zmeny oproti predchádzajúcim pravopisným pravidlám (Pravidlá slovenského pravopisu,1931) takto: „Predovšetkým išlo o to, aby sa zo slovenského pravopisu odstránily rozličné cudzie prvky, ktoré sa doň dostaly vplyvom neželatel'ných pomerov mimojazykových. Preto sme zo slovenského pravopisu vylúčili všetky nepotrebné hláskoslovné, tvaroslovné a iné dvojtvary, ktoré doteraz nebezpečne narúšaly nielen jednotu slovenského pravopisu, ale aj prepotrebnú ustálenost' spisovnej reči. Pri sostavovaní abecedného pravopisného slovníka, ktorý je pripojený k Pravidlám slovenského pravopisu, dbali sme na správnost' a čistotu spisovného jazyka, pričom pridŕžali sme sa zásad Slovenskej reči, ktorá od svojho založenia ciel'avedome buduje jazykovú kultúru slovenskú. Podl'a skutočnej výslovnosti uzákonili sme písanie vžitých cudzích slov, čím podarilo sa nám v mnohých prípadoch oblahčit' doterajší slovenský pravopis. Rozumie sa, že sme nemohli a nechceli opustit' tradíciou ustálený etymologický pravopis, no jednako, kde sa len dalo, usilovali sme sa o to, aby v našom pravopise bolo čím menej t’ažkostí. (...) Pri sostavovaní tohto diela usilovali sme sa, nakol'ko to bolo len možné, nehýbat' zauživanými pravopisnými zvyklost'ami lebo dobre si uvedomujeme, že podstata slovenčiny nie je v pravopisnom systéme, ale najmä v slovníku, frazeológii a skladbe."Elektronická verzia Pravidiel slovenského pravopisu z roku 1940 je dostupná na: <http://www.juls.savba.sk/ ediela/psp1940/psp1940-text.pdf > [cit. 01. 03. 2019].

${ }^{11}$ Vladimír Hurban Vladimírov - vlastným menom Vladimír Konštantín Hurban; prasynovec L’udovíta Štúra a vnuk Jozefa Miloslava Hurbana, v ktorom sa zmiešala krv nepochybne najvýznamnejších osobností slovenskej kultúrnej histórie, zdedil po slávnych predkoch umelecký i organizačný talent. Po štúdiách na gymnáziu v Záhrebe a teológii vo Viedni a v Bratislave pôsobil ako učitel', kaplán a neskôr ako evanjelický farár v Starej Pazove, kde sa popri kňazských povinnostiach venoval najmä literárnej a publicistickej činnosti. Literárne texty uverejňoval pod pseudonymom Vladimír Hurban Vladimírov (najčastejšie pod skratkou VHV), aby sa odlíšil od bratranca, tiež Vladimíra (syna Svetozára Hurbana Vajanského). Písal najmä divadelné hry, teoretické práce o divadle a literatúre, ale aj prózy či jazykovedné štúdie. Bol novátorom v oblasti témy a experimentoval s kompozíciou. Je autorom viacerých drám, historických hier i veselohier, 
konštituovania spisovnej slovenčiny sa Vladimír Hurban Vladimírov (VHV) aktívne zapájal do kultúrno-politických bojov o slovenský jazyk, a to hned' dvoma spôsobmi - v miestnych (vojvodinských) periodikách publikuje popularizačné i teoretické práce o jazyku a zároveň organizuje praktické kurzy o spisovnej slovenčine (hodiny slovenského jazyka určené najmä miestnemu úradníctvu). Názorovo sa prikláňajúc k matičnému centru (nadštandardný osobný vzt’ah mal napríklad so Štefanom Krčmérym) začína už v polovici tridsiatych rokov 20. storočia presadzovat' myšlienku „doplnkového“ jazykového vzdelávania pre obyvatel'ov Starej Pazovy, ktorú neskôr rozvíjal prostredníctvom jazykovednej publicistiky. V čase, ked’ sa spisovná slovenčina nielen upevňovala medzi Slovákmi žijúcimi d’aleko od materskej krajiny, ale sústredila sa tu na ňu aj vedecká pozornost', prichádza zanietený kňaz a už etablovaný dramatik a prozaik s ideou pozdvihovania a posilňovania povedomia Slovákov o materinskom jazyku. Jeho ciel'om bolo pomocou praktických školení (vyučovania), odborných textov a populárno-vednej publicistiky približovat' gramatiku a najnovšiu kodifikáciu spisovnej slovenčiny miestnemu jazykovému spoločenstvu.

Už v roku 1925 vyzýva Hurban v otvorenom liste Slovákov (mužov), aby sa prihlásili na (ním ponúkaný a vedený) kurz slovenského pravopisu, ktorý účastníkom zabezpečí, že po absolvovaní piatich vyučovacích hodín budú „,vediet' slovensky písat'."12 V emóciami okorenenej výzve nezaprel literáta i kňaza, ked’ „pozvanie na vyučovanie slovenského pravopisu“ formuluje ako verejnú výzvu adresovanú miestnej „pánskej“ spoločnosti: „Ctení pánovia, tej jeseni chcem poučovat’ slovenský pravopis. Ak myslíte, že Slovák nemusí a nemá vediet' po slovensky písat', ak myslíte, že Slovák tu v SHS ${ }^{13}$ nesmie vediet' pravopis slovenský, ak myslíte, že je správne písanie svojej materinskej reči tu u nás nepotrebné - tak vás nečakám. Ale ak myslíte, že je to svätá naša povinnost' vediet' slovensky písat' (...) ak ste len trošku - troštičku hrdí na to, že ste Slovák - tak majte tol'ko hrdosti - ale aj úcty k tomu jazyku a naučte sa ho správne písat'. Ja vás volám!"14

Citovaný stimulačný a zároveň i mierne provokujúci apel, vykazujúci prvky angažovanosti, irónie i sarkazmu, nepochybne padol na úrodnú pôdu, o čom svedčí Hurbanova poznámka $\mathrm{k}$ neskôr publikovaným prednáškam o slovenskom pravopi$\mathrm{se}^{15}$ : „Tieto prednášky o pravopise držiaval som pred asi dvoma rokmi v úzkom kru-

rozhlasových hier, napísal operetné libretá a patrí k priekopníkom v tvorbe fillmového scenára. Jeho drámy vykazujú znaky profesionálnych divadelných kultúr európskych vel'komiest a moderných dramatických prúdov (symbolizmu a expresionizmu).

${ }^{12}$ Cit. list uložený v Archíve Slovenskej evanjelickej a. v. cirkvi v Starej Pazove pod inventárnym číslom 292.

${ }^{13}$ SHS - autorom použitá skratka pre názov štátu; oficiálny názov štátu od 15. júla 1920 znel Královstvo Srbov, Chorvátov a Slovincov (Kraljevina Srba, Hrvata i Slovenaca) - odtial' iniciálová skratka SHS pre vyjadrenie názvu krajiny.

${ }^{14}$ Ponuka „kurzu“ slovenského jazyka sa zachovala v podobe rukou písaného listu (možno ide o letáčik - agitačné tlačivo), ktorý sa našiel v Hurbanovej pozostalosti. Cit. list je uložený v Archíve Slovenskej evanjelickej a. v. cirkvi v Starej Pazove pod inventárnym číslom 292.

${ }^{15}$ Prednášky publikoval Hurban pod názvom Sedem hodín o slovenskom pravopise v periodiku Národná jednota a neskôr boli spolu s d'alšími lingvistickými textami uverejnené v publikácii Jazykovedné práce. Pozri Národná jednota, 8, č. 24, 1927: 2-3 (štvrtok 16. júna). 
hu našich Slovákov, ktorí z povolania súc pisármi, najviac prichádzajú do položenia niečo písat' a preto ich povinnost'ou je i slovensky vediet' písat'. Ak to našim gazdom a iným pánom „,nenačim“, pre každého človeka potrebné je, ktorý si namýšl’a byt' Slovákom, aby vedel i slovensky písat'. Je to najväčšia neúcta, ak nie zločin proti svojej materčine, môct' a nechciet' ju správne naučit' sa písat'." (Hurban 2014: 15) Učitel'ské ambície oprášil Hurban znovu o dvadsat' rokov neskôr, ked' pre obyvatel'ov Starej Pazovy otvoril kurz slovenského jazyka pod názvom „Náukobeh slovenčiny“، Nový kurz bol určený pre Pazovčanov a podl'a zachovanej korešpondencie Hurban k nemu pristúpil na základe dopytu od miestnych úradníkov: „Na vašu žiadost' začíname s Novým rokom Náukobeh slovenčiny podelený na tri grupy: I. Učenie slovenského pravopisu, II. Prehl'ad slovenskej spisby, III. Niečo z dejepisu a zemepisu Slovenska. Pre každého Slováka, ktorý žije d’aleko od svojej Matky Slovenska a ktorý je zamestnaný v úradoch, kde treba vediet' písat', potrebuje, aby okrem úradnej chorvátskej reči ${ }^{16}$, v ktorej píše, vedel i svoju materinskú reč písat'." (Hurban 2014: 107) Z d’alšej korešpondencie vieme, že do „náukobehu“ sa Hurbanovi prihlásilo trinást' respondentov a prvé stretnutie bolo plánované na 12. februára 1943 v Slovenskom národnom dome v Starej Pazove. Je pravdepodobné, že kurzy sa napokon aj uskutočnili - zo zachovaných listov sa dozvedáme, že účastníci si zabezpečili aj odporúčanú učebnicu (práve čerstvo vydanú publikáciu Slovačka slovnica autora Dr. Josipa Andrića) ${ }^{17}$ a svedomite sa pripravovali na prvé spoločné stretnutie. Vzdelávanie dospelých v slovenskom pravopise bolo orientované predovšetkým na úradníkov, aby popri úradnej reči vedeli správne písat' aj v reči materinskej. A tí si ako učitel'a slovenčiny vybrali práve Hurbana, ved' v evanjelickom kňazovi a uznávanom literátovi videli najvyššiu jazykovú autoritu (podporenú aj Hurbanovými predchádzajúcimi publikovanými jazykovednými prácami). Uskutočnené jazykové kurzy sú dôkazom, že úlohy kultivátora a propagátora spisovnej slovenčiny sa Hurban nepochybne rád zhostil.

Ako sme už uviedli, do jazykovedného diania a „zápasov“ o spisovnú slovenčinu sa VHV zapojil najmä lingvistickými prácami a publicistikou, ktoré tvoril a uverejňoval v rokoch 1927 - 1940. V čase písania jazykovedných textov sa mohol odvolat' iba na lingvistické práce Samuela Czambela (najmä na Rukovät'spisovnej reči slovenskej), na gramatiku Slovenská mluvnica so zvláštnym zretelom na pravopis (1919) Jána Damborského a neskôr aj na prvú kodifikačnú príručku Pravidlá slovenského pravopisu (1931), s ktorou však často polemizoval a kriticky k nej pristupoval. Pravdepodobne nedostatok normatívnych publikácií a gramatických príručiek v materskej krajine (a následne i v domácom prostredí) a tvrdý zápas o podobu spisovnej slovenčiny v mladučkom Československu priviedli Hurbana k myšlienke ozrejmovat' a vysvetl'ovat' lingvistické javy týkajúce sa slovenského pravopisu, morfológie, lexikológie, etymológie a dialektológie. Nesmierne mu prekážalo, že Slováci žijúci vo Vojvodine neovládajú slovenský pravopis a nevedia správne po slovensky hovorit'. Rozhodol sa preto „učit““ ich ortografiu a vysvetl'ovat' gramatické i vývinové javy spisovnej slovenčiny.

${ }^{16}$ Od apríla 1941 sa Stará Pazova stala súčast’ou Nezávislého štátu Chorvátsko (Nezavisna Država Hrvatska), preto bola úradnou rečou v Starej Pazove chorvátčina. $164 \mathrm{~s}$.

${ }^{17}$ Pozri Andrić, Josip. Slovačka slovnica. Zagreb: Izdanje Hrvatsko-slovačkog društva. 1942. 
Zapálený obhajca spisovnej slovenčiny zanechal množstvo jazykovedných textov (v rukopise i v tlačenej podobe), ktoré súborne vyšli pod názvom Jazykovedné práce. Zostavovatel'ka publikácie Anna Marićová ich rozdelila do troch kapitol. Prvú čast' tvoria práce, ktoré VHV publikoval v rokoch 1927 - 1940 vo vojvodinských periodikách (dvadsat'dva príspevkov bolo uverejnených v Národnej jednote, tri v Našom živote a jeden v Národnom kalendári). Druhú čast’ publikácie predstavujú odpisy zachovaných rukopisných (strojopisných) prác - tri listy adresované obecnému úradníkovi Jánovi Klátikovi (datované z rokov 1942 a 1943) týkajúce sa organizačnej prípravy „Náukobehu slovenčiny“ (vyučovacích hodín slovenského pravopisu) a štrnást' prác venovaných vybraným problémom z oblasti slovenskej morfológie (predložky a predpony, používanie čísloviek, slovies), lexikológie (cudzie slová, zložené slová) a ortografie. Tret'ou čast'ou publikácie je skenovaná podoba rukopisu, ktorý zostavovatel'ka označila ako Slovník cudzích slov od A po $Z$. Autorov rukopis je náročný na čítanie a vzhl'adom na názov sa končí predčasne, prvými heslami písmena „T“. Slová majú od písmena „A“ po začiatočné heslá písmena „,C“ $\left(, \mathrm{K}^{\prime \prime}\right)$ trojčlennú štruktúru - prvé slovo je prevzatie z latinčiny, v zátvorke nasleduje latinský výraz, z ktorého slovo pochádza, a potom slovenský zväčša jednoslovný výklad či ekvivalent. Od litery „,M“ sú už slová takmer nečitatel’né a často pri nich chýba latinský výraz v zátvorke. K slovníku však nie je žiaden opis, nepoznáme okolnosti jeho vzniku a neprešiel ani lexikografickým skúmaním.

Lingvistické príspevky VHV vznikali často ako besednice, väčšinou sú to krátke články, v ktorých sa autor venuje napríklad etymológii slov, onomastike, pravopisným zaujímavostiam, lingvistickým „hračkám“, pričom výklad spestruje popularizačnými prvkami. Rozsiahlejší a štruktúrovaný je už vyššie spomínaný príspevok z roku 1927 nazvaný Sedem hodín o slovenskom pravopise, ktorý je zápisom prípravy na praktické vyučovanie slovenského pravopisu, ktoré Hurban naplánoval najmä pre slovenských (vojvodinských) úradníkov, kňazov a učitel'ov. Ako sme už uviedli, ide o sumár obsahu vyučovacích hodín slovenského pravopisu avizovaných autorom na jeseň roku 1925. V akom rozsahu a či vôbec sa ,hodiny“ slovenského pravopisu konali, to zostáva predmetom nášho d'alšieho výskumu.

Vladimír Hurban Vladimírov v lingvistickom diele akcentoval najmä problematiku slovenskej ortografie, pretože si uvedomoval, že práve vo viacrečovom prostredí so silným nárečovým vplyvom sú ortografické chyby najvypuklejšie a najpočetnejšie. Nový slovenský pravopis vyvolával totiž u vojvodinských Slovákov aj také výzvy, akými bolo úsilie o odstránenie ypsilonu zo slovenčiny. Proti aktivitám nesúcich sa pod heslom „Preč s ypsilonom“ VHV kategoricky vystúpil a horlivo zastával hodžovsko-hattalovskú pravopisnú reformu: „Ja a mnoho druhých by sme sa ne-tešili, keby „,y“ vôbec zmizol. A síce preto, lebo „,y“ je taká hláska ako každá iná - nám ešte chybujú hlásky ku precizovaniu nášho pravopisu - a nie, aby sme sa ,y“ mohli zriect'.“ (Hurban 2014: 30) Protestne reagoval na výzvu k návratu k štúrovskému pravopisu, pričom uvádza protiargumenty a upozorňuje na problémy, ktoré by pri takomto zjednodušení mohli nastat'. Absolútne podporuje pravopis založený na etymologickom princípe. V novinových jazykových príspevkoch sa zameriaval najmä na praktické používanie jazyka, venoval sa napríklad spôsobu písania telegramov Morseovou abecedou v slovenčine, písaniu ženských priezvisk alebo upozorňoval na problematické medzijazykové homonymá (homomorfiu, homofóniu). 
Osobitnú pozornost' venoval Hurban staropazovskému jazyku. V časopise Náš život uverejnil v roku 1933 Slovník staropazovských výrazov z cudzích jazykov, ktorý obsahuje okolo stotridsat' slov označených ako prevzatia z francúzštiny, turečtiny, nemčiny, latinčiny, mad'arčiny, juhoslovančiny, medzi nimi uvádza aj niektoré onomatopoické slová a ,skomoleniny z rôznych jazykov“. V práci pokračoval aj v nasledujúcich rokoch a v roku 1938 uverejnil novú verziu slovníka s takmer štyristo lexikálnymi jednotkami.

V jazykovedných prácach sa VHV zameral na otázky spisovného jazyka v domácom prostredí, na problematiku jazykovej kultúry (korpusového plánovania) a na kontakty slovenčiny a srbčiny. Jeho prvoradým ciel'om bolo priblížit' širšej verejnosti gramatiku (najmä ortografiu) a zákonitosti spisovnej slovenčiny a zároveň sa usiloval uplatňovat’ ich v širokom meradle aj v praxi. Praktická i teoretická lingvistická činnost' pazovského kňaza smerovala k zvyšovaniu úrovne používania spisovnej slovenčiny, k odstraňovaniu častých (návratových) jazykových chýb a cudzích prvkov a bola zameraná najmä na praktickú ortografiu a využívanie domácich slovotvorných postupov pri tvorbe slov. Aby vzbudil čo najširší záujem o spisovný jazyk, publikoval v domácej tlači pútavé a polemické texty, využijúc prostriedky dramatizácie, anekdotickosti a apelatívnosti: „Áno, bud'me dôslední a neoflinkujme svoju reč aspoň vtedy, ked' ju píšeme. Písanie je už akýsi znak kultúry, píšme teda kultúrne a zavrát’me každého škriblera, ked' nevie písat' tak, aby sa mu odnechcelo písat' ale i kritizovat' veci do ktorých sa nerozumie. Apelujem na Slovákov, aby sa učili správne písat' a aby tým práve dokazovali svoju lásku k materinskej reči." (Hurban 2014: 31) V tridsiatych rokoch 20. storočia vidíme teda Hurbana na čele zápasov o identitu spisovnej slovenčiny. Nemusel už potvrdzovat' jej stabilitu a životaschopnost', jeho úlohou bolo zachovat' ju v spisovnej podobe aj v enkláve. Svojím konaním (vyučovanie slovenčiny a odborné lingvistické texty) demonštroval, že aj v enkláve je nevyhnutné napĺn̆at' komunikačnú, reprezentatívnu i estetickú funkciu materinského jazyka.

Jazykovedné texty VHV vyšli bez akýchkol'vek pravopisných či iných úprav, čím poskytujú verný obraz dobového stavu spisovnej slovenčiny vo vojvodinskom prostredí. Nepochybne vyzývajú k d’alšiemu kritickému skúmaniu ako zaujímavý dobový dokument a zároveň inšpiratívny prameň pri výskume dejín slovenskej lingvistiky a stavu a fungovaniu slovenčiny za hranicami materskej krajiny. Lingvistické dielo VHV môže podnietit' $\mathrm{k}$ úvahám o postavení a fungovaní slovenčiny vo Vojvodine dnes, k analýzam „kultivačných“ úsilí domácich filológov v priebehu posledného storočia a napokon aj k otázkam o naplneni vízií staropazovského kňaza na poli lingvistiky.

Vzt’ah Vladimíra Hurbana Vladimírova k problematike súdobej spisovnej slovenčiny bol nepochybne determinovaný pragmatickými okolnost'ami (kultivovat' jazyk úradníkov, učitel'ov, kňazov, zjednodušit' a sprehl'adnit' písanie telegramov, zvyšovat' všeobecnú gramotnost'), ktoré vychádzali z úloh kňaza a učitel'a v spoločenstve používatel'ov slovenčiny za hranicami Slovenska. Jeho záujem o otázky všeobecnej jazykovedy nebol síce hlboký a mal d'aleko aj od vedeckého prístupu, treba však vyzdvihnút' fakt, že Hurbanovo jazykovedné dielo otvára dnes v slovenskej lingvistike - napriek uvedenému - viaceré otázky. Našou úlohou tak zostáva ,vystopovat“" Hurbanov lingvistický vplyv v enkláve a zistit’, či vízie ukazujúce cestu do „lepšej“ budúcnosti slovenčiny naplnil primeraným obsahom. Ved’ špecifické procesy prebiehajúce v jazyku slovenského jazykového spoločenstva vo Vojvodine v medzivojnovom období nepo- 
chybne presahujú do súčasnosti, v zmysle potvrdenia predikovanej tézy o opakujúcich sa (návratových) jazykových procesoch vo vojvodinskej slovenčine.

Takmer tristoročný styk slovenčiny s príbuzným jazykom (srbským) a zároveň chýbajúci priamy kontakt s jazykom v materskej krajine vytvárali osobitú formu jazyka v tejto slovenskej enkláve. (Dudok 2010, Myjavcová 2001). Slovenčinu vojvodinských Slovákov formovali najmä špecifické jazykové kontakty - jazyk minoritných Slovákov sa obohacoval o nové výrazové prostriedky kontaktových jazykov (proces prirodzený vo všetkých bilingválnych jazykových spoločenstvách), došlo v ňom ku gramatikalizácii jazykových prostriedkov a možno v ňom sledovat' výrazné fonetické a syntaktické stopy vyplývajúce z koexistencie s majoritnou srbčinou. (Dudok 2004, Myjavcová 2015). Osobité spoločenské, politické a kultúrne podmienky vývinu slovenčiny vo Vojvodine formovali jej dávnu (medzivojnovú) i súčasnú podobu. Tú minulú (nepochybne už dávno zabudnutú) podobu nájdeme dnes v lingvistickom diele VHV, ktorý sa nad predchádzajúcim vývinom, súčasným stavom a perspektívami spisovného jazyka zamýšlal takmer dve desat'ročia. Zo sledovania zápasu o spisovnú slovenčinu v materskej krajine (,,boj“ o Pravidlá slovenského pravopisu) mu nepochybne vyplynula povinnost' zaangažovat' sa v úsilí o reformu spisovnej slovenčiny aj medzi Slovákmi vo Vojvodine. Do akej miery sa evanjelickému kňazovi podarilo aplikovat' nové gramatické normatívy do podoby enklávnej slovenčiny nám v budúcnosti umožní sprostredkovat' konfrontačný výskum prostredníctvom uskutočnenej komparácie komunikátov z medzivojnového obdobia a zo súčasnosti. Naším zámerom však nie je kritika stavu slovenského jazyka vo vojvodinskom prostredí, ale analýza tohto stavu a diferencovaný pohl'ad na jazyk enklávy v minulosti i v súčasnosti.

\section{Literatúra}

Andrić, Josip. Slovačka slovnica. Zagreb: Izdanje Hrvatsko-slovačkog društva. 1942. 164 s. Bartek, Henrich. „Ešte o správnosti jazykovej. Odpoved’ na Vážneho úvahy nad Slovenskou rečou“. Slovenská reč. Roč. II, č. 9-10, 1933: 278-296.

Bogoczová, Irena. „Statusové a korpusové plánovaní jako součást jazykové politiky“. [In:] Čeština - jazyk slovanský 4. Ed. R. Šink. Ostrava: Pedagogická fakulta Ostravskej univerzity v Ostrave, 2010, 171-180.

Czambel, Samuel. Rukovät' spisovnej reči slovenskej. Turčiansky sv. Martin: Kníhkupecko-nakladatel'ský spolok, 1902.

Dudok, Miroslav. „O diasporálnej slovenčine“. Jazykovedný časopis, roč. 61, č. 1, 2010: $65-70$.

Dudok, Miroslav. „Pluricentrický vývin modernej slovenčiny“. [In:] Studia Academica Slovaca 31. Red. J. Mlacek. Bratislava: Stimul, 2002, 42-50.

Dudok, Miroslav. „Pulzačné vektory enklávnej slovenčiny“. [In:] Slovenčina v menšinovom prostredí. Ed. A. Uhrinová - M. Žiláková. Békešská Čaba: Výskumný ústav Slovákov v Mad'arsku, 2004, 32-42.

Hurban, Vladimír Vladimírov. Jazykovedné práce. Zost. Anna Marićová. Báčsky Petrovec: Slovenské vydavatel'ské centrum, 2014. 
Kristal, Dejvid. Enciklopedijski rečnik moderne lingvistike. Beograd: Nolit, 1988.

Kristal Dejvid. Smrt jezika. Beograd: Biblioteka XX vek, 2003.

Myjavcová, Mária. O slovensko-srbskom bilingvizme vo Vojvodine. Báčsky Petrovec:

Slovenské vydavatel'ské centrum, 2015.

Myjavcová, Mária. Slovenčina v jazykovej enkláve. Báčsky Petrovec - Nadlak: Kultúra - Vydavatel'stvo Ivan Krasko, 2001.

Novák, L’udovít. Jazykovedné glosy k československej otázke. Turčiansky Svätý Martin: Matica slovenská, 1935.

Nekvapil, Jiř́i (2017). Jazykové plánování. In: Petr Karlík, Marek Nekula, Jana Pleskalová (eds.), CzechEncy - Nový encyklopedický slovník češtiny. URL: https://www.czechency. org/slovnik/ JAZYKOVÉ PLÁNOVÁNÍ (poslední přistup: 25. 10. 2019)

Ondrejovič, Slavomír. „Henrich Bartek - známy i neznámy“. Slovenská reč, roč. 72, č. 3, 2007: 129-133.

Pravidlá slovenského pravopisu a abecedným pravopisným slovníkom. Praha: Štátne nakladatel'stvo. Vydala Matica slovenská, 1931.

Sokolović, Dalibor. „O manjinskim slovenskim jezicima iz perspektive ekologije jezika na primeru lužičkih Srba i vojvođanskih Slovaka“. Doktorska disertacija. Beograd: Filološki fakultet, 2014.

Švagrovský, Štefan. „Jazykovedné dielo S. Czambla v osídlach politiky“. Slovenská reč, 71, č. 6, 2006, 330-339.

Žigo Pavol, „Konfliktnost’ kodifikačných snáh Henricha Bartka“. Slovenská reč, roč. 72, č. 3, 2007: 166-173.

\section{Juliana Beňová}

\section{JEZIČKO PLANIRANJE U LINGVISTIČKOM DELU VLADIMIRA HURBANA VLADIMIROVA}

\section{Rezime}

Rad se bavi problematikom jezičkog planiranja u lingvističkom delu Vladimira Hurbana Vladimirova (VHV) u periodu između dva svetska rata. Korpusno planiranje (corpus planning), koje za cilj, između ostalog, ima i brigu o slovačkom književnom jeziku realizuje se ne samo u matičnoj državi, već i u slovačkim jezičkim enklavama u Vojvodini. Komplikovana jezička situacija u Čehoslovačkoj između dva svetska rata (1918-1938), formiranje savremenog slovačkog kao i pojava novih Pravila slovačkog pravopisa (1931) - sve ovo je imalo uticaj na jezik vojvođanskih Slovaka. VHV se aktivno uključio u kulturno-političku borbu za slovački jezik sa idejom da ojača i podigne na viši nivo svest Slovaka o maternjem jeziku, pri čemu su mu kao platforma za delovanje poslužili lokalne periodične publikacije i tečajevi jezika za domaće stanovništvo. Namera VHV je bila da pomoću praktičnog obrazovanja, stručnih tekstova i popularno-naučne literature približi gramatiku i najnoviju kodifikaciju slovačkog književnog jezika lokalnoj jezičkoj zajednici. Hurbanovo delo otvara nekoliko pitanja o intenzitetu i stabilizaciji jezičkog korektiva u enklavi među sledećim generacijama govornika slovačkog jezika. Specifični procesi koji su se dešavali u periodu između dva rata u jeziku vojvođanskih Slovaka imaju uticaj i na sadašnjost u smislu potvrde teze o jezičkim procesima koji se ponavljaju u okviru vojvođanskog slovačkog jezika. Posebni društveni, politički i kulturološki uslovi razvoja slovačkog jezika u Vojvodini su formirali njen davni (međuratni) i sadašnji oblik. U kojoj meri se pojavni oblici slovačkog jezika 
u enklavama razlikuju može da nagovesti uporedno istraživanje putem realizovane komparacije komunikata iz međuratnog perioda i sadašnjosti.

Ključne reči: problematika jezičkog planiranja, korpusno planiranje, komplikovana jezička situacija u Čehoslovačkoj; Pravila slovačkog pravopisa (1931), jezički korektiv, lingvističko delo Vladimira Hurbana Vladimirova. 